\title{
Vulnerability Assessment and Adaptation Costs of Agriculture to Climate Change in the Lima Region, Peru
}

\author{
Edelina Coayla and Elizabeth Culqui
}

\begin{abstract}
In the face of climate change, the characteristics of vulnerable sectors generate information on adaptation strategies, but the most important challenge is to assess the adaptation costs. This paper assesses climatic vulnerability in order to estimate the costs of agricultural adaptation to climate change in the region of Lima, Peru. Five indices of crop vulnerability to climate change impacts (from low to severe) were designed based on agricultural and water monitoring and surveys of farmers conducted during on-site workshops. The costs of two main climate change adaptation measures (base year 2017) were estimated, for the period 2017-2030: 1) implementation of contingency plans for water protection in the basins of Lima region (US \$ 26.63 million), and 2) climate change adaptation for one crop (US \$ 652.18 equivalent annual cost per hectare). Standardizing baselines to assess "business as usual" costs of climate change, without adaptation measures for the agriculture sector, is encouraged. This study allows the prediction of agricultural vulnerability until 2030 , and at the same time it is preventive for farmers in order to make decisions about climate change in the coming years.
\end{abstract}

Index Terms-Vulnerability, agriculture, climate change, adaptation costs.

\section{INTRODUCTION}

In response to observed climate change and the severity of its possible impacts, the United Nations has established two main forums: the United Nations Framework Convention on Climate Change (UNFCCC); and the Intergovernmental Panel on Climate Change (IPCC). IPCC conducts periodic assessments of climate change around the world. Based on IPCC recommendations, UNFCCC has developed two strategic lines of action in the face of the two broad challenges posed by climate change: mitigation and adaptation. Mitigation consists of reducing greenhouse gas emissions and/or increasing the absorption of carbon dioxide from the atmosphere through carbon sinks. Adaptation refers to activities carried out by individuals or systems in order to prevent, to resist or take advantage of climate change and its impacts, whether current or anticipated [1].

Adaptation requires analysis of the vulnerability of the components of a system exposed to climatic events and the identification of adaptation measures, either to reduce vulnerability or to benefit from possible opportunities. Vulnerability is defined as "the propensity or predisposition to be adversely affected" and encompasses a variety of

Manuscript received July 8, 2019; revised October 23, 2019.

E. Coayla is with Faculty of Economic Sciences, Universidad Nacional Federico Villarreal, Peru (corresponding author; e-mail: edelinacoayla@yahoo.es).

E. Culqui is with ECD Ambiente, Peru (e-mail: eculqui@gmail.com). elements, including sensitivity or susceptibility to harm and lack of capacity to cope with climate change and adapt (IPCC, [2]).

Tol [3] estimates the impacts of climate change in the 20th century and extrapolates it to the 21 st century. The fertilization of carbon dioxide from crops and the reduction in energy demand for heating are the main positive impacts he identifies. Meanwhile, he notes that climate change has a negative impact on water resources and on human health. Most countries benefited from climate change until 1980, but from that point on, the trend became negative for poor countries and positive for rich countries. The overall average impact was positive in the 20th century. But starting from the 21 st century, the impacts are negative in most countries, rich and poor alike. The main negative effects are felt in energy demand, water resources, biodiversity and sea level rises.

Calzadilla et al. [4] argue that the impacts of climate change on agriculture are worrisome, considering adaptation to be beyond the management capacity of most farming and selection processes. They investigate the effects of expanded irrigation and accelerated technological progress in South Africa, and argue that climate change could alter agricultural productivity through five main factors: rainfall, temperature, fertilization by carbon dioxide (CO2), climate variability and surface water runoff changes. Agricultural production is directly influenced by rainfall and temperature changes.

Rainfall is the main source of all freshwater resources and determines the level of soil moisture. It is also the main contributor to yield variability ([4]).

Metternicht et al. [5] describe a methodological framework for carrying out climate change vulnerability, impact and adaptation (VIA) assessments in the Latin American sub-regions, and globally, through the Regional Gateway for Technology Transfer and Climate Change Action in Latin America and the Caribbean (REGATTA).

Global agricultural lands included sizeable areas of Australia, China, Brazil, the United States and Saudi Arabia. Countries with very arid climates (such as Algeria, Libya, Egypt, Saudi Arabia, Niger) and arid climates (such as Australia, Chile, South Africa, Iran, Kazakhstan and China) will be more affected by climate change. The shortage of agricultural production due to climate change will greatly affect the world's economic balance (Ozcan and Strauss, [6]).

Abaje et al. [7] focus on the impact of climate change on the families of selected rural communities in the state of Kaduna, Nigeria, and the adaptation strategies of these families. The study identifies the decline of crops, decreased soil fertility, increased disease and declining forest resources among the most significant climate impacts in the area. Meanwhile, the use of animal manure as fertilizer, water harvesting, economic tree plantations and drought-resistant 
crops, among others, are the main sustainable adaptation strategies adopted by rural people.

Mallari [8] uses the average volume of rainfall, average typhoon wind speed, and the growth stage of plants during a typhoon as sensitivity indicators for a vulnerability assessment of Typhoon Santi in The Philippines, and propose a proportion of agricultural land as well as access to credit and/or crop insurance as sources of adaption capacity.

As far as Paquin [9] is concerned, decision-makers often prioritize the social importance of an activity without taking into account its impact on the climate and the urgency of this problem. Adequate prioritization and allocation of resources must ensure that the necessary attention is paid to the prevailing risks.

According to Galindo et al. ([10]: 16) there are different estimates of adaptation costs for Latin America, although all have a high level of uncertainty.

Their comparison of climate change impacts with adaptation costs show that while the costs do not exceed $0.5 \%$ of the region's GDP, the expected impacts go beyond $1.5 \%$ of regional GDP. Therefore, it is important to implement efficient adaptation measures to reduce the negative impacts of climate change ([10], p.18).

According to UNEP [11], adaptation costs in developing countries were previously estimated at between US\$70 billion and US\$ 100 billion per year for the period 2010-2050, but it is now thought they could range between US\$ 140 billion and US $\$ 300$ million per year by 2030 , and between $\$ 280$ billion and $\$ 500$ billion per year by 2050 (UNEP). The costs of adapting to climate change are determined by the size of the existing adaptation gap - that is, the difference between the costs of adaptation and the funding available at a given time.

For Siña et al. [12], climate change poses multiple risks for the population of Lima, the capital of Peru, located in a desert ecosystem on the Pacific coast. These risks include greater water scarcity, increased heat, and vector transmission and other climate-sensitive diseases.

Kim et al. [13] assessed agricultural adaptation strategies in Cambodia to sustainable rice yields under climate change. By using an investment model based on real options, they identify that irrigation is a viable option and the most effective strategy to reduce the negative impacts of climate change for the agricultural sector.

Adaptation to climate change in smallholder agriculture is vital to reducing rural poverty, adaptation is a two-step process that first requires farmers to perceive climate change and secondly that they respond to changes through adaptation (Asrat and Simane, [14]).

Asrat and Simane [14] found that farmers living in the dry lowland area perceive more changes in climate than farmers in the wet lowlands, approximately $47 \%$ of respondents in the wet lowlands and $44 \%$ in the dry lowlands they have adopted soil and water conservation practices.

Hellin \& Fisher [15] use the example of the Western Highlands in Guatemala to illustrate how a focus on the number of farmers adopting climate-smart agriculture (CSA) as an adaptation option to climate change, can encourage a tendency to homogenize farmers, instead of recognizing differentiation within agricultural populations; for many farmers, agriculture in itself does not represent a pathway out of poverty, and they are increasingly dependent on sources of non-agricultural income.

Mashizha [16] applied an intentional sampling technique by interviewing 40 Zimbabwean peasant farmers, who recognized that the decrease in rainfall over the past 30 years has reduced agricultural productivity, and in response, communities have developed multiple adaptation strategies such as use of social capital, crop and livelihood diversification, participation in small businesses and collection of water for livestock; and therefore, the diversification of adaptation strategies is vital for a sustainable livelihood in a changing climate.

Parker et al. [17] develop a robust methodology, flexible to data limitations and spatially prioritize the vulnerability of agriculture to climate change assuming that vulnerability is equal to: $50 \%$ potential impact (sensitivity and exposure) and $50 \%$ adaptive capacity and they have applied it in Vietnam, Uganda and Nicaragua. Using both data and crop models, they capture the sensitivity of key crops to climate change, integrated exposure to natural hazards that affect agricultural systems and rural areas, and adopted a wide range of indicators to represent adaptive capacity.

The present study is justified because the treatment of the climate cuts across disciplines, regions and economic sectors, and so the contribution of different actors is required. It is important for the design and implementation of public policies and strategies for climate adaptation in favor of sustainable development in Peru.

The objective of this study is to devise a vulnerability assessment and estimate the costs of agricultural adaptation to climate change in the Lima region.

Based on the vulnerability analysis for the agricultural sector of the Lima region, it was found that the main adaptation options to climate change for the period 2017-2030 are the implementation of contingency plans and water protection, the anticipated dissemination of the climate forecasts and training on crops resistant to climate change.

\section{MATERIALS AND METHOdS}

Temporal and spatial scope: The study encompasses a vulnerability assessment and an estimation of the costs of climate adaptation for the agricultural sector in the Lima region of Peru by 2030.

Materials: Sources of information and documentation: INEI, SENAMHI, IMARPE statistics. Workshops with farmers. Software: Excel, Google Earth, MM5, SPSS

Data collection techniques: Primary information (workshops, surveys) on vulnerability and adaptation to climate change in the Lima region. Secondary information: water, agriculture and climate.

\section{A. Procedure}

First, two training workshops on vulnerability and adaptation to climate change were conducted, and a survey questionnaire was designed to obtain information on the vulnerability of farmers to climate change in the Lima region. The workshop participants were both managers and users of the Irrigation Boards of the Chancay-Huaral district and the 
Caqui subsector, and the survey was applied to the participants face- to- face in May and August 2017, respectively.

The questionnaire consisted of three sections, with a mix of closed selection, ranking, and quantitative / monetary questions. Section A obtained a set of socioeconomic data (gender, age, main activity) pertaining to the respondents. Section B focused on the respondents' knowledge level about climate change in general and the "El Niño" phenomenon in particular, including the causes and climatic impacts on agriculture. Section C explored the costs of economic losses caused by climate change and the El Niño phenomenon from January to March 2017, as well as the actions, recommendations and adaptability of farmers in the Lima region. For the study, 36 valid questionnaires (that is, those answered in full) were utilized.

To ascertain prevention strategies for the following summer rainy season (2018) the interview with the president of the Irrigation Board of the Chancay-Huaral district, Lima region, was used as a survey instrument.

Second, the characteristics of the vulnerability to climate change faced by most farmers in the Lima region were assessed. Then, climate change vulnerability indexes and adaptation measures were developed. Finally, the main adaptation measures and costs for agriculture in the Lima region were estimated and analyzed, based on the methodology of Doornbos ([18]).

\section{RESULTS}

The region of Lima contains nine provinces: Barranca, Cajatambo, Canta, Cañete, Huaral, Huarochirí, Huaura, Oyón and Yauyos. The Lima region has an area of 28,470.76 $\mathrm{km} 2$, and its capital is Huacho $(67 \text { m.a.s.l. })^{1}$. Its lowest altitude is 12 m.a.s.l. (Las Salinas, Huacho) while it highest is 6634 m.a.s.l. (Nevado Yerupajá - Cajatambo).

\section{A. Climate Change Impact Assessment for Agriculture in the Lima Region}

According to INEI [19], the annual agricultural production of Lima region is more than 400,000 tons of alfalfa, more than 800,000 tons of corn and more than 100,000 tons each in the case of sweet potato, potato, tangerine and apple.

The Lima region was impacted by climate change in the form of a decrease in planting intentions from 93,665 hectares in 2013-2014 to 61,177 hectares in August 2015 to July 2016. The main crops are corn, sweet potatoes and potatoes (Ministry of Agriculture - MINAGRI, 2016).

TABLE I: LIMA REGION, PLANTING INTENTIONS AND PLANTED AREA PER Growing SEASON, AUGUST 2015-July 2018- (HECTARES)

\begin{tabular}{|c|c|c|c|c|c|c|}
\hline \multirow[t]{2}{*}{$\begin{array}{l}\text { Peru/ Lima } \\
\text { region }\end{array}$} & \multirow{2}{*}{\multicolumn{2}{|c|}{$\begin{array}{c}\text { Planting } \\
\text { intention } \\
2017-2018\end{array}$}} & \multicolumn{2}{|c|}{ Growing season } & \multicolumn{2}{|c|}{$\begin{array}{c}2017-18 \\
\text { intention/ } \\
2016-17 \\
\text { growing } \\
\text { season } \\
\end{array}$} \\
\hline & & & 2015-2016 & $\begin{array}{c}2016-2017 \\
\text { p }\end{array}$ & $\%$ & $\mathrm{Ha}$ \\
\hline $\begin{array}{l}\text { TOTAL } \\
\text { PERU }\end{array}$ & $\begin{array}{r}2,308,52 \\
4\end{array}$ & 100.0 & $2,133,480$ & $2,108,540$ & 9.5 & $\begin{array}{r}199, \\
985\end{array}$ \\
\hline
\end{tabular}

\footnotetext{
${ }^{1}$ The province of Metropolitan Lima, which contains the capital city, is administratively independent and not included as part of the region.
}

\begin{tabular}{|l|rr|r|r|rr|} 
Lima region & 62,246 & 2.7 & 65,201 & 57,477 & 8.3 & 4,769 \\
Metropolitan & & & & & -19. & \\
Lima & 1,943 & 0.1 & 2,709 & 2,406 & 2 & -463 \\
\hline
\end{tabular}

${ }^{\mathrm{p}}$ Provisional, ${ }^{\mathrm{r}}$ Revised

Source: MINAGRI (ENIS 2017 and EMDA 2014-2015-2016 2017).

The planted area in the growing season of August 2016 July 2017 , decreased by $12 \%$ compared with the previous season of 2015-2016 due to the El Niño phenomenon of summer 2017. However, planting intentions from August 2017 to July 2018 recovered by $8 \%$ in relation to the 2016-2017 season.

TABLE II: LIMA PROVINCES: CONSUMPTIVE USE OF SURFACE WATER FROM THE PACIFIC BASIN, 2013-2015

\begin{tabular}{|c|c|c|c|c|c|}
\hline $\begin{array}{l}\text { Local water } \\
\text { administration }\end{array}$ & Total & Agricultural & Industrial & $\begin{array}{c}\text { Public/residen } \\
\text { tial }\end{array}$ & Mining \\
\hline \multicolumn{6}{|l|}{2015} \\
\hline Barranca & $559,584,912$ & $539,010,000$ & $10,680,890$ & $9,622,194$ & 271,828 \\
\hline Huaura & $813,746,057$ & $802,731,536$ & $7,568,640$ & $1,954,970$ & $1,490,911$ \\
\hline $\begin{array}{l}\text { Chancay-Hua } \\
\text { ral } \\
\text { Mala-Omas-C }\end{array}$ & $328,816,554$ & $322,665,200$ & 12,145 & $5,664,014$ & 475,195 \\
\hline añete & $375,742,045$ & $361,580,000$ & $4,462,431$ & $5,773,382$ & $3,926,232$ \\
\hline \multicolumn{6}{|l|}{2014} \\
\hline Barranca & $777,083,391$ & $756,407,000$ & $10,434,594$ & 10080449 & 161,348 \\
\hline $\begin{array}{l}\text { Huaura } \\
\text { Chancay-Hua }\end{array}$ & $10,612,844$ & - & $7,568,640$ & 1892938 & $1,151,266$ \\
\hline $\begin{array}{l}\text { ral } \\
\text { Mala-Omas-C }\end{array}$ & $325,869,032$ & $320,423,228$ & 12,145 & 5350015 & 83,644 \\
\hline $\begin{array}{l}\text { añete } \\
2013\end{array}$ & $268,973,922$ & $134,767,500$ & $1,261,440$ & 132235422 & 709,560 \\
\hline Barranca & $832,522,232$ & $811,350,000$ & $10,911,753$ & $9,805,616$ & 454,863 \\
\hline $\begin{array}{l}\text { Huaura } \\
\text { Chancay-Hua }\end{array}$ & $985,393,766$ & $974,764,524$ & 7,582225 & $1,847,657$ & $1,199,360$ \\
\hline $\begin{array}{l}\text { ral } \\
\text { Mala-Omas-C }\end{array}$ & $328,974,430$ & $324,126,475$ & 12,145 & $4,725,434$ & 110,376 \\
\hline añete & $744,897,682$ & $607,909,356$ & $2,621,784$ & $130,503,182$ & $3,863,360$ \\
\hline
\end{tabular}

Regarding the consumptive use of fresh water, agricultural activity accounted for the largest volume of water use in the Lima region - around $95 \%$ of the total - in the period 2013-2015 (Table II).

To collect information on climate change vulnerability conditions and the impact of the El Niño phenomenon (January to March 2017) on the agricultural sector of Lima region, two workshops were held for managers and users from the irrigation boards of Chancay district (Huaral province) and the Caqui subsector, at which these participants received climate change vulnerability training and completed surveys. These events took place in May and August 2017, respectively.

Of the 36 valid surveys, $82 \%$ of the participants responded that they engage exclusively in agricultural activity, while $15 \%$ said that they combine agriculture with other activities (Fig. 2). Meanwhile, $44 \%$ are educated to higher level (because the majority of respondents manage irrigation 
sub-sectors), $78 \%$ are men, $71 \%$ are over 51 years old, and, on average, they have three children.

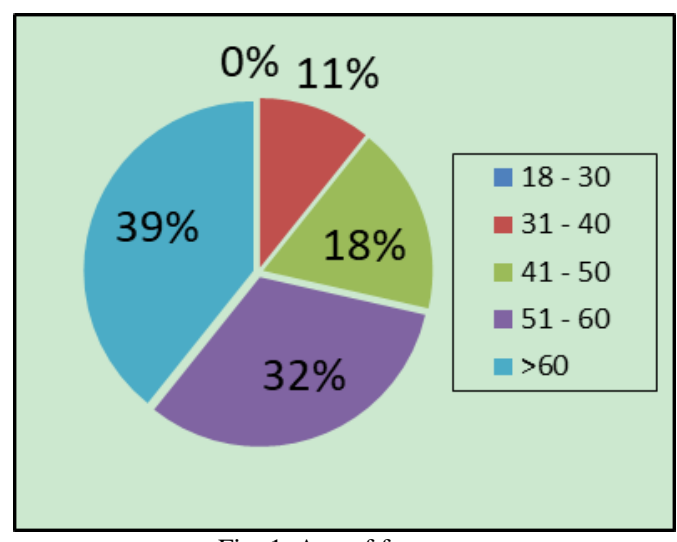

Fig. 1. Age of farmers.

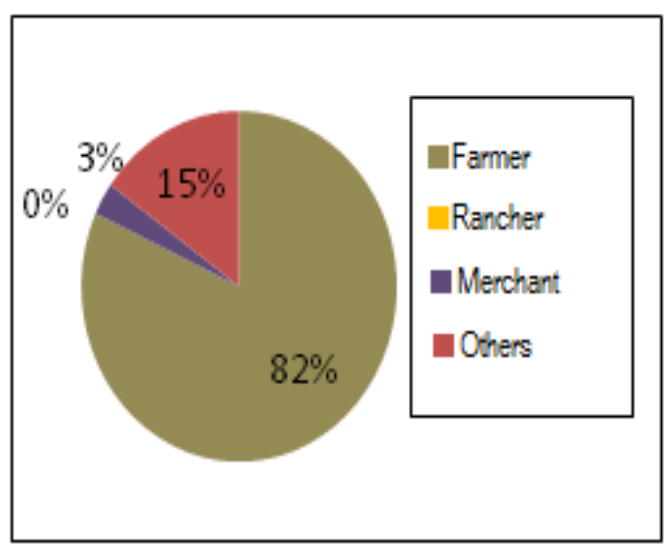

Source: Authors

Fig. 2. Main activity.

As to knowledge of climate change, $55 \%$ of farmers were aware that the fumes and gases released by industry generate high temperature and greenhouse emissions, while $25 \%$ cited carbon monoxide and carbon dioxide as greenhouse gases. Finally, $85 \%$ of respondents connected the natural disasters of January to March 2017 in Lima to climate change (Fig. 3).

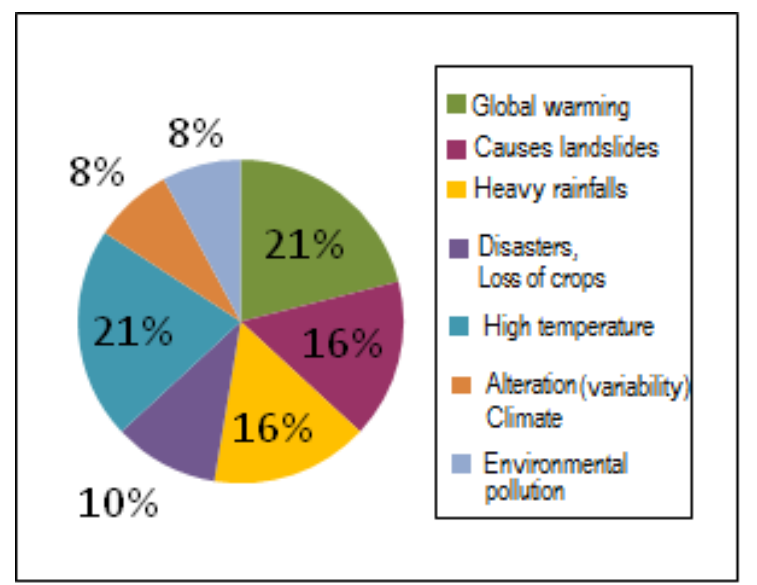

Fig. 3. Disasters and climate change, 2017.

All (100\%) farmers stated that the El Niño phenomenon causes problems for agriculture in the Lima region, identifying the problems as follows: $38 \%$ reported loss of crops; $37 \%$ observed disasters, floods, river overflows and damage to the irrigation infrastructure; and $12 \%$ said it caused more plagues (Fig. 4).

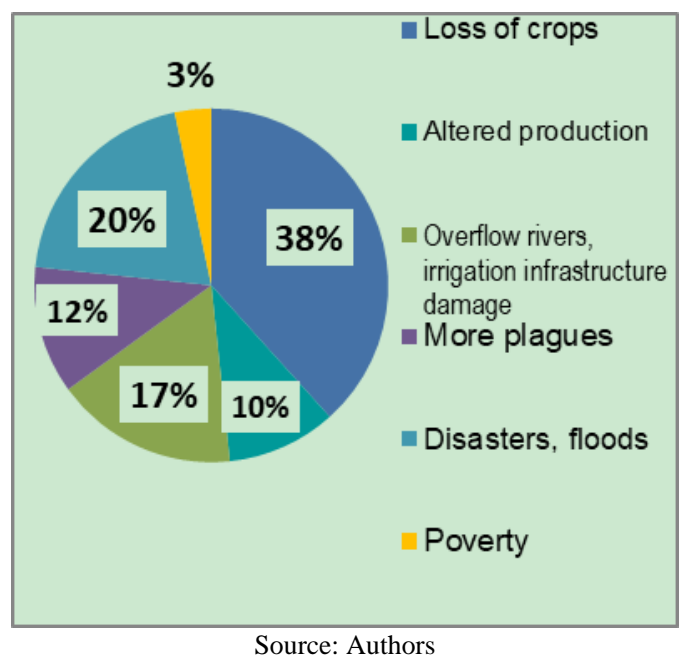

Fig. 4. Problems in the sector.

On the question of which authorities to turn to, $44 \%$ of farmers concerned about climate change and the El Niño phenomenon suggested going to the regional government; $32 \%$ would go to the municipality of Huaral and/or the Ministry of Agriculture and the National Water Authority (ANA); and $13 \%$ related that they would coordinate with all entities related to agriculture.

A majority of farmers (55\%) recommended that the government (ministries, municipalities) must prepare adaptation plans and projects in order to avoid damage to agriculture in the face of climate change and the El Niño phenomenon, while $32 \%$ said they should prepare contingency plans and take actions to prevent overflows of rivers.

When it comes to effects on yields, $85 \%$ of the surveyed farmers stated that the El Niño phenomenon of 2017 caused damage to their productivity. The most damaging consequences of climate change for farmers in the Lima region (Chancay-Huaral) are droughts (28\%), high temperatures (27\%), and pests (19\%) (Fig. 5)

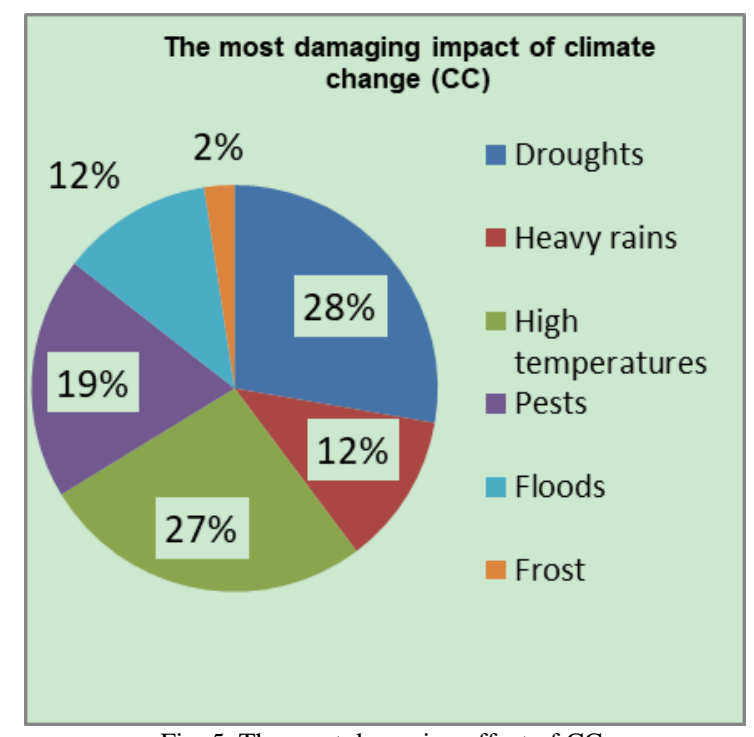

Fig. 5. The most damaging effect of CC.

The main forms of economic loss caused by climate change according to the farmers of the Lima region are decreased harvests $(41 \%)$, decreased product profitability 
$(33 \%)$, and both the deterioration of arable land and switches to other crops (20\%) (Fig. 6).

Economic losses caused by climate change (CC)

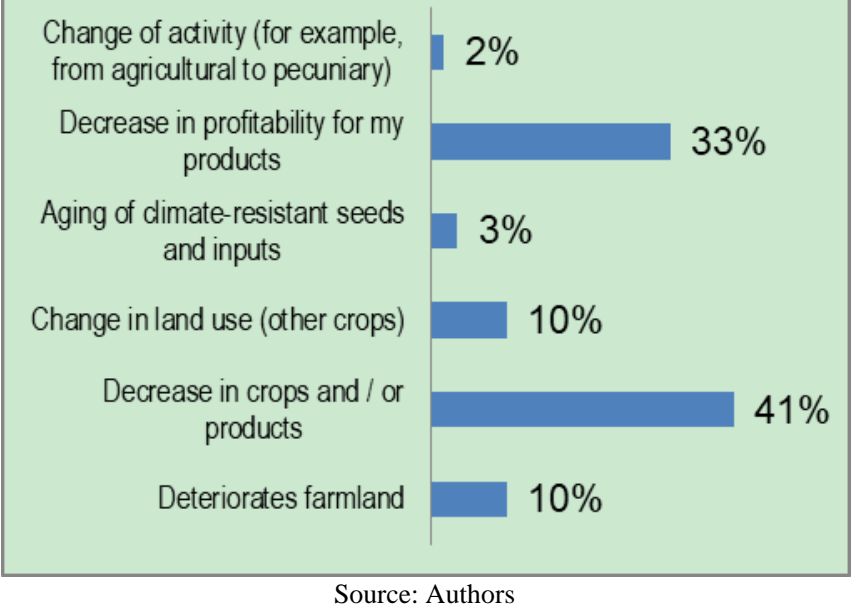

Fig. 6. Economic losses by climate change.

Based on the vulnerability analysis for the agricultural sector of the Lima region, it was found that the main adaptation options to climate change for the period 2017-2030 are the implementation of contingency plans and water protection, the anticipated dissemination of the climate forecasts and training on crops resistant to climate change. Based on the vulnerability analysis for the agricultural sector of the Lima region, it was found that the main adaptation options to climate change for the period 2017-2030 are the implementation of contingency plans and water protection, the anticipated dissemination of the climate forecasts and training on crops resistant to climate change.

On the other hand, $72 \%$ of farmers surveyed said they were not being prepared to face climate change. Of this total, $50 \%$ felt the need for support from the authorities, $25 \%$ noted a lack of technical training for farmers, and $20 \%$ needed more guidance on what crops to sow in the face of climate change.

As to the types of support needed, the farmers suggested timely information on climate change (35\%), government support in prevention (31\%), economic compensation for severe El Niño events (17\%), and more accessible agricultural loans for people over $70(13 \%)$.

On January 29, 2018, Juan Enriquez Balabarca, farmer and president of the Irrigation Users Board of the Chancay-Huaral district, stated in an interview that after a year of extreme weather events in the Chancay river basin caused by the El Niño phenomenon in Summer 2017, rehabilitation management was costly and had been sacrificed. Indeed, the rehabilitation and decolonization of the rivers has been delayed, and of the 39 kilometers planned, only nine kilometers were ultimately rehabilitated. The only decoupled river is the Huaura River. The Ministry of Agriculture- MINAGRI does not support them or train them on crops that resist climate change (high temperatures, pests).

Mr. Enriquez stressed the reactivation of the Cultivation and Irrigation Plan, because years ago, farmers had information on how to achieve profitable crops without oversupply, whereas at present farmers plant potatoes, corn and apples in excessive quantities. Currently, uncertainty worsens the consequences of climate change, such as new pests that attack crops. In addition, he recommended that MINAGRI and especially the regional government of Lima prepare a comprehensive agrarian plan for 2030 based on water assurance projects in the Lima region, training, and export and/or agro-industrialization projects, and the promotion of production chains by MINAGRI.

\section{B. Climate Modeling for the Lima Region}

\section{1) Lima temperature}

The variation in altitude from sea level to the Andean areas directly influences the behavior of temperature and atmospheric humidity. The average annual temperature at sea level is $18{ }^{\circ} \mathrm{C}$, which decreases as one ascends the Andean peaks. The highest temperatures are recorded in February, with average monthly maximum and minimums of $27^{\circ} \mathrm{C}$ and $20{ }^{\circ} \mathrm{C}$, respectively, at Jorge Chávez International Airport; $29{ }^{\circ} \mathrm{C}$ and $20{ }^{\circ} \mathrm{C}$ in Cañete; and $27{ }^{\circ} \mathrm{C}$ and $19{ }^{\circ} \mathrm{C}$ in Paramonga. The lowest temperatures occur in August, with maximum average temperatures of $19{ }^{\circ} \mathrm{C}$ and $20{ }^{\circ} \mathrm{C}$ and minimums of $14{ }^{\circ} \mathrm{C}$ or $15{ }^{\circ} \mathrm{C}$, in Cañete and Lima, respectively. August is also marked by cloud cover, high humidity, frequently drizzle at night and in the early hours of the day and low temperatures.

\section{2) MM5 mesoscale meteorological model}

This study is based on the MM5, the fifth generation of the mesoscale model developed at Pennsylvania State University alongside the NCAR (National Center for Atmospheric Research), the origins of which date to the early 1970s.

For climate modeling, programs such as Excel, Google Earth were required, and a Linux operating system was used for the installation of the model. The methodology employed for temperature modeling involved completing missing data from the stations by taking the average from a ratio of the most adjacent stations, then the temperatures were projected using the trend of the MPIFM model from a previous study with statistical elements that come closest to the data employed here. Finally, an online tutorial method was used for the installation of the MM5 model.

\section{3) Historical data for temperature modeling in the Lima region}

The data was obtained from SENAMHI [20], initially for eight weather stations: Donoso, Pacarán, Lomas de Lachay, Huayán, Camay, Alcantarilla, University of Huacho and Socsi Cañete; in the case of the last two stations, the number of years of variable registration was not sufficient to determine the temperature climatology, so these were only used to complete data for nearby stations.

\begin{tabular}{|r|l|l|l|l|l|}
\hline \multicolumn{7}{|c|}{ TABLE III: LOCATION OF WEATHER STATIONS } \\
\hline$\#$ & Weather station & Lat. & Lon. & $\begin{array}{l}\text { Alt } \\
\text { m.a.s.m. }\end{array}$ & $\begin{array}{l}\text { Obs. } \\
\text { Ob. }\end{array}$ \\
\hline 1 & Donoso & $11^{\circ} 31^{\prime} 15.6^{\prime \prime}$ & $7^{\circ} 14^{\prime} 8.4^{\prime \prime}$ & 133 & 33 \\
\hline 2 & Pacarán & $12^{\circ} 52^{\prime} 08^{\prime \prime}$ & $\begin{array}{l}76^{\circ} 03^{\prime} 28.55 \\
"\end{array}$ & 683 & 52 \\
\hline 3 & $\begin{array}{l}\text { Lomas de } \\
\text { Lachay }\end{array}$ & $1^{\circ} 21^{\prime} 36.38^{\prime \prime}$ & $7^{\circ} 22^{\prime} 6.28^{\prime \prime}$ & 412 & 53 \\
\hline 4 & Huayán & $11^{\circ} 27^{\prime} 10.1^{\prime \prime}$ & $77^{\circ} 07^{\prime} 19.2^{\prime \prime}$ & 351 & 52 \\
\hline
\end{tabular}




\begin{tabular}{|r|l|l|l|l|r|}
\hline 5 & Camay & $1^{\circ} 54^{\prime} 46.7^{\prime \prime}$ & $77^{\circ} 38^{\prime} 56^{\prime \prime}$ & 65 & 47 \\
\hline 6 & Alcantarilla & $1^{\circ} 03^{\prime} 38.44^{\prime \prime}$ & $77^{\circ} 33^{\prime} 38^{\prime \prime}$ & 130 & 50 \\
\hline 7 & $\begin{array}{l}\text { Universidad de } \\
\text { Huacho }\end{array}$ & $1^{\circ} 7^{\prime} 25.9^{\prime \prime}$ & $\begin{array}{l}77^{\circ} 36^{\prime} \\
21.7^{\prime \prime}\end{array}$ & 45 & 8 \\
\hline 8 & Socsi & $13^{\circ} 1^{\prime} 42^{\prime \prime}$ & $76^{\circ} 11^{\prime} 40.3^{\prime \prime}$ & 500 & 22 \\
\hline
\end{tabular}

\section{4) Location of weather stations}

The weather stations identified were located geographically using the Google Earth program.

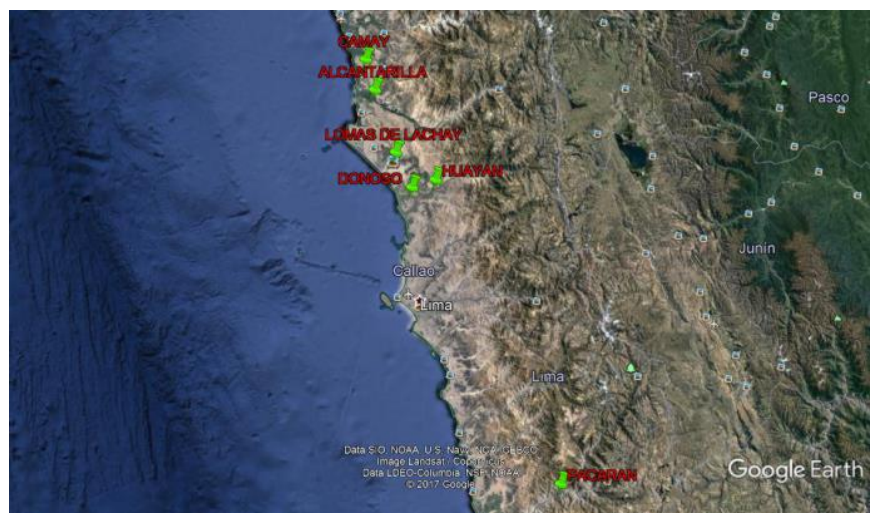

Fig. 7. Location of Lima weather stations.

It can be observed that the weather stations of Donoso and Camay are closer to the coast, while those of Pacaran and Huayan are continental points (Fig. 7).

5) Sea surface temperature trend of the MPIFM and CSIRO models

This trend was obtained from a previous study that projects quarterly temperatures to the year 2050: January March (JFM); April - June (AMJ); July - September (JAS); and October - December (OND).

TABLE IV: STATISTICAL PARAMETERS FOR THE CSIRO AND MPIFM MODELS, QUARTERLY BASIS

\begin{tabular}{|c|c|c|c|c|c|c|}
\hline \multirow{2}{*}{ Period } & \multicolumn{3}{|c|}{ Csiro B2 Model } & \multicolumn{3}{c|}{ MPIfM A2 Model } \\
\cline { 2 - 7 } & $\begin{array}{c}\text { Mean } \\
\left({ }^{\circ} \mathrm{C}\right)\end{array}$ & $\begin{array}{c}\text { Standard } \\
\text { deviation }\end{array}$ & $\begin{array}{c}\text { Annual } \\
\text { trend } \\
\left({ }^{\circ} \mathrm{C}\right)\end{array}$ & $\begin{array}{c}\text { Mean } \\
\left({ }^{\circ} \mathrm{C}\right)\end{array}$ & $\begin{array}{c}\text { Standard } \\
\text { deviation }\end{array}$ & $\begin{array}{c}\text { Annual } \\
\text { trend } \\
\left({ }^{\circ} \mathrm{C}\right)\end{array}$ \\
\hline JFM & 26.59 & 0.40 & 0.026 & 26.22 & 0.59 & 0.016 \\
\hline AMJ & 25.19 & 0.38 & 0.025 & 24.79 & 0.67 & 0.016 \\
\hline JAS & 21.73 & 0.45 & 0.029 & 21.23 & 0.86 & 0.010 \\
\hline OND & 22.59 & 0.39 & 0.025 & 22.30 & 1.02 & 0.014 \\
\hline
\end{tabular}

Using these values, the temperature trend was modeled for the six stations in the Lima region.

6) Modeling of station temperatures

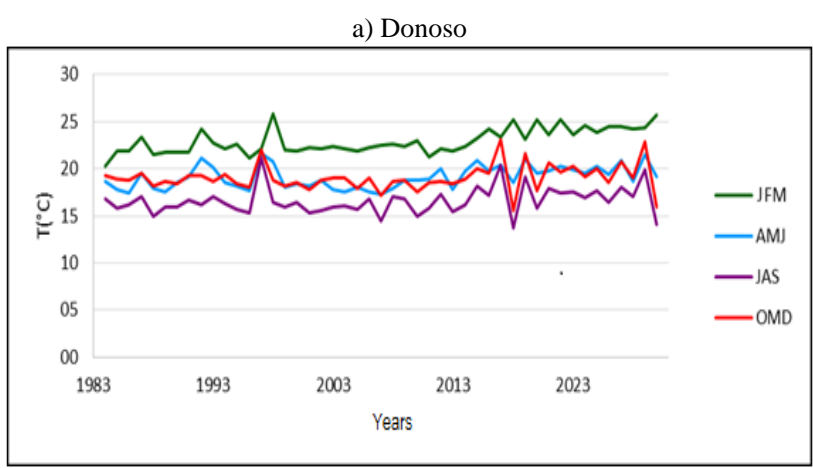

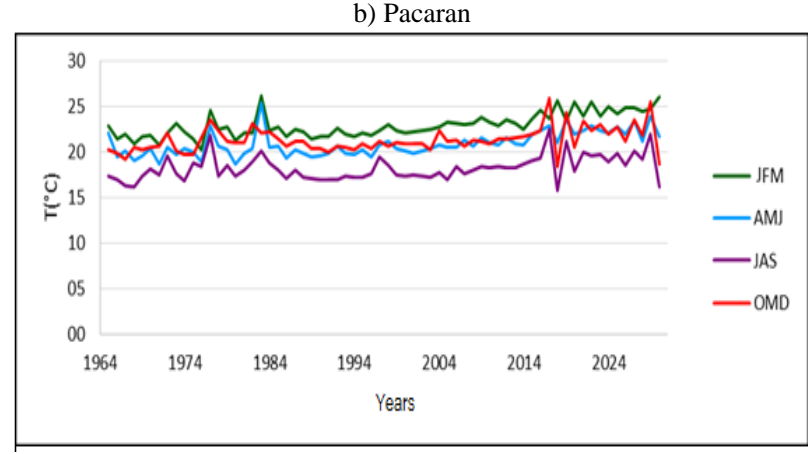

c) Lomas de Lachay
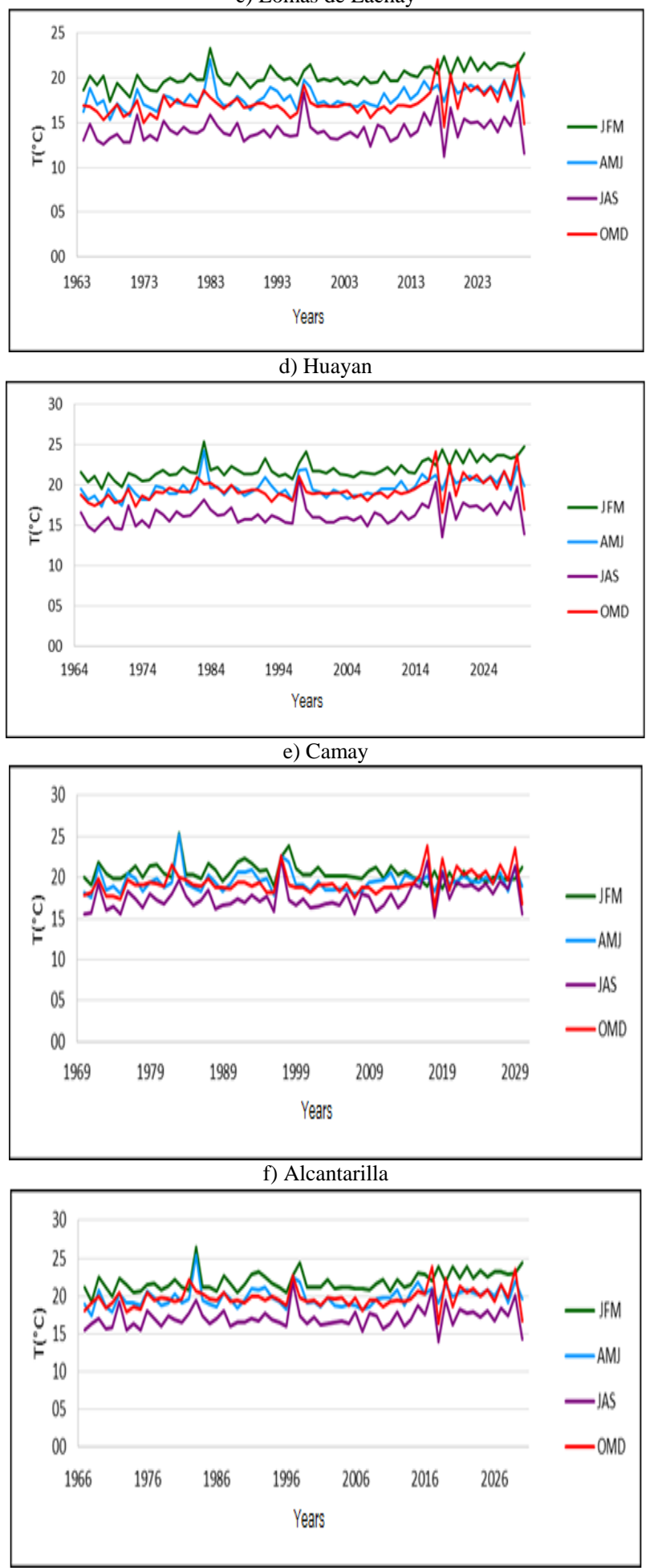

Fig. 8 (a-f). Climate variation of the temperature.

In the Fig. 8 a)-f) shown, the temperature peaks observed 
up to 2016 correspond to the years marked by El Niño events. According to these projections, temperatures for the year 2030 will fall within the normal range. However, by 2029, a slight increase in temperatures is expected in most of the localities. This increase in temperature will be greatest at Pacaran point, with average temperatures above $22{ }^{\circ} \mathrm{C}$ forecast. This increase could mean the occurrence of an $\mathrm{El}$ Niño event.

\section{Vulnerability Analysis, Main Measures and Adaptation Costs for the Lima Region}

Indices of vulnerability were constructed from the vulnerability assessment of climate change impacts on farmers in the Lima region.

a) Agricultural vulnerability to climate change was assessed by crop types.

b) Indices of vulnerability were estimated based on surveys completed by farmers from the Lima region affected by the 2017 El Niño event, (Table Va). Based on these indices, the level of vulnerability of the region's crops was rated (Table $\mathrm{Vb})$.

TABLE VA: INDICES OF VULNERABILITY IN AGRICULTURE

\begin{tabular}{|l|r|l|}
\hline Index & $\%$ & Range \\
\hline V. Serious & $>70$ & 70 and above \\
\hline IV. Very high & 40 & 40 to 69 \\
\hline III. High & 25 & 25 to 39 \\
\hline II. Normal & 5 & 5 to 24 \\
\hline I. Low & $<5$ & \\
\hline \multicolumn{2}{|r|}{ Source: Authors }
\end{tabular}

TABLE VB: INDICES OF CROP VULNERABILITY

\begin{tabular}{|l|r|l|}
\hline Loss of crops & \% & Index of vulnerability \\
\hline Corn & 30 & High \\
\hline Corn husk & 33 & High \\
\hline Fuerte avocado & 50 & Very high \\
\hline Hass avocado & 80 & Serious \\
\hline Strawberry & 56 & Very high \\
\hline Tangerine & 75 & Serious \\
\hline Apple & 50 & Very high \\
\hline Orange & 62 & Very high \\
\hline Mango & 100 & Serious \\
\hline Green beans & 73 & Serious \\
Source: Authors & \multicolumn{2}{|}{} \\
\hline
\end{tabular}

According to the indices of crop vulnerability, Index IV points to the very high vulnerability of the fuerte avocado, and to the advisability of adapting by changing to corn and corn husk - the least affected crops.

The agriculture sector in the Lima region is vulnerable to climate change considering the maximum temperature variables in its agricultural valleys and the rainfall in the upper basin of its rivers, including the Huaura, Huaral, Chancay and Cañete. This vulnerability to climate change is exacerbated by the fact that most of those engaged in agriculture are on the brink of old age and do not have other sources of income; because the economically active population of the Lima region is largely employed in non-agricultural activities, which provide better opportunities and quality-of-life prospects, a change of land use in the region, predominantly in favor of construction, industry and commerce, seems likely.

The sector's vulnerability to climate change has already manifested itself through increases in maximum temperatures and rainfall, as occurred between January and March 2017 during the El Niño phenomenon. As a consequence, farmers reported flooding of their agricultural plots, plagues and crop loss, all of which are indicators of vulnerability.

Given this vulnerability to climate change in the sector, there is a need to analyze the actions that farmers recommend to adapt to it, considering that IPCC, in addition to providing guidance on adaptation to climate change, recommends that vulnerable agents from the sectors affected propose the best way of adapting so as to mitigate damage.

Farmers suggest that key actors participate actively in climate monitoring in the Lima region; however, they are already immersed in technology, and recommend usage of the forecasts disseminated on a regular basis. Likewise, they recommend adequate and coordinated multisectoral management among all the key entities. One of the weaknesses cited by the sector is the lack of management in terms of prevention, monitoring and dissemination of possible climate change events. In response, farmers recommend contingency plans and training to help them adapt to climate change, as well as investment projects for irrigation infrastructure and river protection works.

The analyzed crops have indices ranging from $30 \%$, denoting high vulnerability, to more than $70 \%$, indicative of serious vulnerability. The latter figure followed crop losses due to the El Niño event in 2017, standing as evidence that the agricultural sector in the Lima region is very vulnerable to climate change.

For Viola et al. [21] adaptation is defined as "the adjustment in human or natural systems in response to real or expected climate stimuli, or their effects, which may moderate the damage or exploit the beneficial opportunities". Adaptation reduces the risks of climate change.

Adaptation measures can be planned in advance or implemented spontaneously in response to local pressure. They include infrastructure changes - such as the construction of defenses to protect against rising sea levels or road improvements to withstand high temperatures and changes - and even behaviors such as reducing water use. Adaptation to climate change includes the adoption of measures to counteract the associated effects and vulnerabilities, both now and in the future, and, in general, the variability that occurs in the context of a changing society, regardless of climate change.

Vulnerability to climate change is determined by three factors: exposure to risks (such as decreased rainfall); sensitivity to these risks (for example, an economy dominated by rainfed crops); and the ability to adapt to these risks (for example, whether farmers have money or skills to develop new crops that are more resistant to drought). Adaptation measures can help reduce vulnerability - by reducing sensitivity or ensuring greater adaptability, for instance - as well as allowing populations to benefit from the opportunities of climate change, such as the growth of new crops in areas to which they were not previously suited (Viola et al. [21]).

\section{1) Adaptation measures in agriculture}

- Preparation and implementation of climate change contingency plans (El Niño, overflowing rivers, 
floods);

- Management to prevent overflow of rivers, floods and mudslides;

- Execution of irrigation infrastructure projects and works to protect riverbeds;

- Timely dissemination of information and weather forecasts;

- Training on adaptable (alternative) crops to climate change in the area under study.

\section{2) Adaptation costs}

According to Doornbos [18] (p.18) adaptation costs can be estimated using two methods: one based on current investments in climate sensitive sectors, under the assumption that climate change will lead to additional costs of around $10 \%$ of this investment; and another based on an attempt to identify and evaluate the necessary investments in each of the sectors affected.

To estimate climate change adaptation costs, this paper uses a combination of both methods: identifying and evaluating the necessary investments in each of the affected sectors (Doornbos, [18]) while assuming that climate change will lead to additional costs, calculated as a percentage of this investment valued at current cost. 2017 is taken as the base year. Moreover, climate change is a long-term system with occurrences of strong El Niño events every decade or so. And according to the results of the climate model based on SENAMHI data from stations in the Lima region, it is expected that the next strong El Niño event will occur around 2029.

Considering an annual study period of 2017-2030, and a discount rate of $4 \%$ for the agricultural sector, the current (2017) cost of adapting the measure "preparation and implementation of contingency plans in the face of climate change (El Niño Phenomenon, overflow of rivers, floods)" is calculated at 87.9 million Peruvian soles (US\$ 26.63 million) for the basins of the Lima region. This base cost was based on normal business as usual (BAU) conditions, without implementation of the measure, taking into account the value of infrastructure projects and irrigation system upgrade and maintenance in 2017, as per the modified institutional budget (PIM) for the agriculture sector in the Lima region.

For the second adaptation measure "timely dissemination of information and weather forecasts" in the agricultural sector, a current cost of 2.1 million soles was estimated for 2017.

For the third measure "training on adaptable crops (alternative) to climate change in the area under study" the cost of adaptation, updated to 2017, it is 699.2 thousand soles.

We also estimated the costs of adaptation of corn, a crop resistant to high temperatures, with a high (but not serious) vulnerability index for the period 2017-2030, assuming an additional cost of adaptation of $30 \%$. The cost of production under normal BAU conditions gave rise to the updated cost of 428.1 million soles per hectare and 21,491 soles (US\$ 6,512) of the current cost, to 2017. Expressed in terms of annual equivalent cost per hectare, this would be 2,152.19 soles (US\$ 652.18).

\section{DISCUSSION}

Rising temperatures and changing rainfall patterns have direct effects on crop yields, as well as indirect effects through changes in irrigation water availability. In agriculture, adaptation efforts focus on the implementation of measures that help promote rural livelihoods that are more resilient to climate variability and disasters (International Food Policy Research Institute, [22]). In the Lima region, the number of hectares under crops has decreased due to climate change: by $12 \%$ in the case of the August 2016-July 2017 growing season, compared with the previous season of 2015-2016, as a result of the El Niño phenomenon in the summer of 2017.

Consumptive use of water decreased in 2015 compared to 2013 (Table II), pointing to a reduction in planting intentions in the Lima region given that agriculture accounts for about $95 \%$ of the usage of freshwater from the Pacific basin.

In the case of rice farmers in southern Spain, Iglesias et al. [23] identify a lack of generational renewal due to the decline in young farmers, arguing that the sector's main adaptation options are new water infrastructure and agricultural subsidies. The same is true in the Lima region, where a predominance of older farmers make the sector more vulnerable. For the present study, one of the main adaptation options is the implementation of contingency plans for the prevention and protection of water infrastructure in the Lima region.

Mthembu and Zwane [24] discuss the relationship between the vulnerability and adaptive capacity of small farmers in KwaZulu-Natal in South Africa, arguing that the lack of information and early warning systems, including regular weather reports, leads to deficient risk assessment. This is similar to the experience of farmers in the Lima region. Therefore, based on the vulnerability assessment, this paper proposes the adaptation measure "timely dissemination of information and weather forecasts".

Mustafa et al. [25] argue that adaptation is a process that consists of three stages and finds that farmers first perceive climatic variations $(71.4 \%)$, then trying to adapt $(58.5 \%)$ and finally succeed in adapting to climatic variation (40.2\%). They find that education and perception have a positive and significant impact in all three stages and recommend that in the long term governments increase education, while in the short term they should increase farmers' awareness to speed up the adaptation process. They also recommend that governments give price incentives to farming communities to increase their capacity for adaptation. In Peru and the Lima region, farmers demand government support in adapting to climate change.

In short, and according to UNEP [11], there is no single best way of estimating the costs of adaptation.

For future research, there is a need to standardize methodologies for estimating adaptation costs by sectors, regions and countries, especially BAU cost baselines for climate change without adaptation measures.

There are numerous studies that analyze both vulnerability and adaptation options in the agricultural sector ([7], [8], [13], [14], [16], [17], [21], [24], among others), but those do not include the costs of adaptation. The contribution of this study was to estimate in monetary terms the costs of adapting 
agriculture to climate change, urging progress in the construction of adaptation cost baselines.

This study is of a scientific nature because with historical meteorological data and long-term weather forecasts, statistical methods of trends are used to obtain on-site temperature forecasts until 2030. In addition, it is applied and interdisciplinary because through surveys and workshops aimed at farmers in the study area, the climate change impact is related to the El Niño phenomenon to measure its effect in terms of vulnerability in agriculture and adaptation costs.

\section{CONCLUSIONS}

Agriculture and water resources are vulnerable to climate change in the Lima region. Lima's Farmers say the most damaging consequences of climate change are droughts, high temperatures and plagues in the region. This causes economic losses mainly due to lower yields, decreases in the profitability of their products and degradation of arable land.

Most farmers believe that they are not prepared to face climate change. They point out that they need government support for their prevention efforts, technical training and guidance about which crops to plant, timely information on climate change, and economic compensation following the recent serious El Niño event. In addition, they require more accessible agricultural loans for elderly farmers, who are the most vulnerable.

According to climate modeling, average temperatures above $22{ }^{\circ} \mathrm{C}$ are expected for 2029 , accompanied by the probable occurrence of an El Niño event.

Based on the vulnerability assessment for the Lima region, it was found that the main climate-change adaptation options and costs for the period 2017-2030 are the implementation of contingency and water protection plans for the basins of the Lima region at a current cost of US\$ 26.63 million, as well as adaptation to crops resistant to climate change at an annual equivalent cost of US\$ 652.18 per hectare.

This study estimated in terms of present value, the adaptation costs of agriculture to climate change, urging the standardization of calculation methodologies and the BAU cost base lines without adaptation, for the agriculture sector of Peru and the rest of the countries.

\section{CONFLICT OF INTEREST}

The authors declare no conflict of interest.

\section{Author CONTRIBUtions}

E. Coayla conducted the research and wrote the paper; E. Culqui analyzed the data; all authors had approved the final version.

\section{REFERENCES}

[1] IPCC, "Cambio climático 2014: Informe de síntesis. Contribución de los Grupos de trabajo I, II y III al Quinto Informe de Evaluación del Grupo Intergubernamental de Expertos sobre el Cambio Climático," Equipo Principal de Redacción, Ginebra, Suiza, vol. 157, 2014.

[2] Oficina de Cambio Climático, Plan Nacional de Adaptación al Cambio Climático, Ministerio del Medio Ambiente, Chile, 2014.

[3] R. Tol, "The economic impact of climate change in the 20th and 21st centuries," Climatic Change, vol. 117, pp. 795-808, April 2013.
[4] A. Calzadilla, T. Zhu, K. Rehdanz, R. Tol, and C. Ringler, "Climate change and agriculture: Impacts and adaptation options in South Africa," Water Resources and Economics, vol. 5, pp. 24-48, 2014.

[5] G. Metternicht, A. Sabelli, and J. Spensley, "Climate change vulnerability, impact and adaptation assessment. Lessons from Latin America," International Journal of Climate Change Strategies and Management, vol. 6, no. 4, pp. 442-476, 2014.

[6] A. Ozcan and E. Strauss, "An overview of the global climate change on farmland in Turkey," International Journal of Environmental Science and Development, vol. 7, no. 6, pp. 458-463, June 2016.

[7] I. Abaje, B. Sawa, E. Iguisi, and A. Ibrahim, "Impacts of climate change and adaptation strategies in rural communities of Kaduna State," Ethiopian Journal of Environmental Studies and Management, vol. 9, no.1, pp. 97-108, January 2016.

[8] A. Mallari, "Climate change vulnerability assessment in the agriculture sector: Typhoon Santi experience," Procedia - Social and Behavioral Sciences, vol. 216, pp. 440-451, 2016.

[9] D. Paquin, R. Elía, S. Bleau, I. Charrona, T. Logan, and S. Biner, "A multiple timescales approach to assess urgency in adaptation to climate change with an application to the tourism industry," Environmental Science \& Policy, vol. 63, pp. 143-150, 2016.

[10] L. Galindo, J. Samaniego, J. Alatorre, and J. Carbonell, Procesos de adaptación al cambio climático. Análisis de América Latina, CEPALColección Documentos de Proyecto, Diciembre 2014.

[11] UNEP, The Adaptation Finance Gap Report 2016, United Nations Environment Program (UNEP), Nairobi, Kenya, 2016.

[12] M. Siña, R. Saldarriaga, J. Lawler, J. Zunt, P. Garcia, and C. Cárcamo, "Understanding perceptions of climate change, priorities, and decision-making among Municipalities in Lima, Peru to better inform adaptation and mitigation planning," PLOS ONE, vol. 25, pp. 1-13, January 2016.

[13] J. Kim, H. Park, J. A. Chun, and S. Li, "Adaptation strategies under climate change for sustainable agricultural productivity in cambodia," Sustainability, vol. 10, pp. 1-18, December 2018.

[14] P. Asrat and B. Simane, "Farmers' perception of climate change and adaptation strategies in the Dabus watershed, North-West Ethiopia," Ecological Processes, vol. 7, no. 7, pp. 1-14, February 2018.

[15] J. Hellin and E. Fisher, "Climate-smart agriculture and non-agricultural livelihood transformation," Climate, vol. 7, no. 48, pp. 1-8, March 2019.

[16] T. M. Mashizha, "Adapting to climate change: Reflections of peasant farmers in Mashonaland West Province of Zimbabwe," Jàmbá: Journal of Disaster Risk Studies, vol. 11, no.1, March 2019.

[17] L. Parker, C. Bourgoin, A. Martinez-Valle, and P. Läderach, "Vulnerability of the agricultural sector to climate change: The development of a pan-tropical Climate Risk Vulnerability Assessment to inform sub-national decision making," PLOS ONE, vol. 14, no.3, pp.1-25, March 2019.

[18] B. Doornbos, "Experiencias en adaptación al cambio climático en Latinoamérica: Avances en políticas públicas nacionales, el accionar local de proyectos y una reflexión sobre su articulación," ASOCAM, 2011.

[19] INEI, Compendio estadístico Lima Provincias 2014, p. 588, 2015

[20] SENAMHI, "Temperature and rainfall statistics, stations of the Lima region 1984- 2017," 2017.

[21] I. Viola, I. Borrelli, G. Carbone, M. De Angelis, R. Misso, and G Cesaretti, "Climate change: The result of an economic model strategy oriented towards the trade approach," Quality-Access to Success, vol. 17 , no. S1, pp. 481-491, June 2016.

[22] Instituto Internacional de Investigación sobre políticas alimentarias, Cambio climático, el impacto en la agricultura y los costos de adaptación, 2009

[23] A. Iglesias, B. Sanchez, L. Garrote, and I. López, "Towards Adaptation to Climate Change: Water for Rice in the Coastal Wetlands of Doñana, Southern Spain," Water Resource Manage, vol. 31, pp. 629-653, April 2017.

[24] N. N. Mthembu and E. M. Zwane, "The adaptive capacity of smallholder mixed-farming systems to the impact of climate change: The case of KwaZulu-Natal in South Africa," Jàmbá Journal of Disaster Risk Studies, vol. 9, no. 1, November 2017.

[25] G. Mustafa, I. Latif, M. Ashfaq, M. Bashir, M. Shamsudin, and W. Daud, "Adaptation process to climate change in Agriculture - An empirical study," International Journal of Food and Agricultural Economics, vol. 5, no. 4, pp. 81-98, 2017

Copyright (C) 2020 by the authors. This is an open access article distributed under the Creative Commons Attribution License which permits unrestricted 
use, distribution, and reproduction in any medium, provided the original work is properly cited (CC BY 4.0).

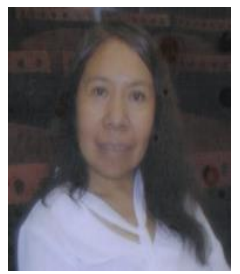

Edelina Coayla is an economist, the master in economics from the Pontificia Universidad Católica de Perú and the doctor in engineering from the Universidad Nacional Federico Villarreal (UNFV). With specialization courses in environmental economics by the Beijer International Institute of Ecological Economics (Brazil), Ecological principles for sustainable development by the Organization for Tropical Studies - OTS and the Universidad de Costa Rica. Currently, she is a research professor (National Registry of Science and Technology-RENACYT) in the Faculty of Economic Sciences - UNFV with many years of experience in research work on environmental economics and climate change, environmental regulation and mitigation costs of GHG emissions in Peru. She was a member of the project research team: Planning for climate change - PlanCC, Peru, 2013-2014 (industrial processes).

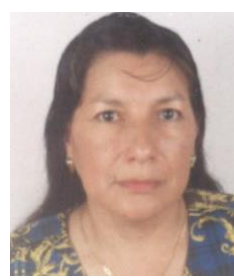

Elizabeth Culqui is a meteorologist engineer with a postgraduate in environmental leadership from the Santa Cruz Institute in Tucson Arizona; environmental meteorology and conservation of forest resources in the Universidad Nacional Agraria La Molina (UNALM) and the doctorate in environment and sustainable development in the Universidad Nacional Federico Villarreal. She is professor. She has experience in the preparation of inventories about substances emission sources into the atmosphere, atmospheric modeling, environmental impact assessment. She has worked as a specialist in supervision and as a consultant in environmental issues at the Ministry of the Environment, Peru. Lead researcher in the industrial processes sector PlanCC, Peru. She has published in the Scientific Annals of the UNALM "Study of potential air pollution in the area of Morococha and La Oroya". Currently, she is an environmental consultant for the company ECD Ambiente. 